\title{
Peningkatan Pemahaman Dasar Akuntansi Mahasiswa melalui Penerapan Direct Instruction Dengan Media Worksheet
}

\author{
Riski Ayu Arnila1* ${ }^{*}$ Hidayatul Ahyani²
}

1,2Universitas Gunung Rinjani, Lombok Timur - Indonesia

\section{A R T I C L E I N F O \\ Article history: \\ Received November, 1 2021 \\ Received in revised form November, 272021 \\ Accepted December, 12021 \\ Available online December, 252021}

Kata Kunci:

Direct instruction, laporan

keuangan, worksheet.

Keywords:

Direct instruction, financial report, worksheet.

\section{A B S T R A K}

Tujuan utama dari penelitian ini adalah untuk meningkatkan pemahaman dasar akuntansi mahasiswa dengan penggunaan model Direct Instruction (DI) pada materi laporan keuangan dengan media worksheet. Penelitian ini adalah penelitian tindakan dengan subjek penelitian mahasiswa Pendidikan Akuntansi Universitas Gunung Rinjani. Teknik pengumpulan data dengan observasi, wawancara, dokumentasi dan tes. Sementara data dianalisis dengan menggunakan metode kombinasi dengan tipe convergen parallel mixed methods. Hasil penelitian menunjukkan bahwa penggunaan model Direct Instruction (DI) dengan media worksheet dapat meningkatkan pemahaman dasar akuntansi mahasiswa pada materi penyusunan laporan keuangan. Peningkatan pemahaman mahasiswa ditunjukkan dengan berbagai perubahan dalam kemampuan mahasiswa dari segi kemampuan mahasiswa dalam menyusun laporan laba rugi, kemampuan mahasiwa dalam menyusun laporan perubaha modal, dan kemampuan mahasiswa dalam menyusun neraca. Peningkatan pemahaman dasar akuntansi mahasiswa ditandai juga dengan peningkatan nilai rata-rata pemahaman dasar akuntansi yakni nilai rata-rata mahasiswa dari 20,00 pada tahap pratindakan menjadi 49.33 setelah tindakan siklus 1 dan kembali meningkat setelah tindakan siklus 2 dengan nilai rata- rata 80,67 kemudian meningkat kembali setelah pemberian tindakan siklus 3 dengan nilai ratarata 84.33. Setelah tindakan siklus 2 dan 3 sejumlah 93,33\% mahasiswa berhasil meningkatkan pemahaman dasar akuntansi yang dimiliki.

\section{A B S T R A C T}

The aim of this study is to improve students' basic understanding of accounting by using the Direct Instruction (DI) model on financial statement materials using worksheet media. This research is action research with research subjects of Accounting Education students at Gunung Rinjani University. Data collection techniques by observation, interviews, documentation and tests. While the data analysis technique used is quantitative and qualitative data analysis, the combination method used is a convergent parallel mixed method. The results indicate that implemantation of Direct Instruction (DI) model with worksheet media can improve students' basic understanding of accounting. The increase in students' basic understanding is shown by various changes in students' abilities in terms of students' abilities in preparing income statements, preparing Statement of Retained Earnings, and students' abilities in preparing balance sheet. The increase in students' basic understanding of accounting in this study was also marked by an increase in the average value of basic accounting understanding, the average value of students from 20.00 before receiving the action to 49.33 after receiving the action in cycle 1 and increasing again to 80.67 after receiving the action. in cycle 2 and increased to 84.33 in cycle 3 . In cycles 2 and 3,93.33\% of students succeeded in increasing their basic understanding of accounting.

\footnotetext{
* Corresponding author.

E-mail : riskiayuarnila@gmail.com (Riski Ayu Arnila)
} 


\section{Pendahuluan}

Mata kuliah pengantar akuntansi atau dasar- dasar akuntansi merupakan mata kuliah wajib yang harus ditempuh oleh mahasiswa Pendidikan Akuntansi. Mata kuliah ini ditempuh pada semester awal dan menjadi mata kuliah prasyarat untuk menempuh beberapa mata kuliah akuntansi di semester berikutnya. Setiap mahasiswa diharuskan untuk lulus pada mata kuliah ini baru diperbolehkan untuk menempuh mata kuliah akuntansi yang lain pada semester berikutnya, hal ini dikarenakan pemahaman dasar akuntansi sangat penting untuk membantu dalam memahami materi- materi akuntansi pada mata kuliah selanjutnya seperti mata kuliah akuntansi keuangan menengah, akuntansi keuangan lanjutan, akuntansi koperasi, dsb. Akan tetapi kelulusan mahasiswa pada mata kuliah ini tidak menjamin tingginya pemahaman mereka terhadap akuntansi dasar, hal seperti ini terjadi pada mahasiswa Pendidikan Akuntansi Universitas Gunung Rinjani (UGR). Hampir seluruh mahasiswa lulus pada mata kuliah ini namun sebagian besar dari mereka yang lulus justru mengeluhkan kurangnya pemahaman terhadap akuntansi dasar yang menjadikan mereka mengalami kesulitan saat mengikuti beberapa mata kuliah akuntansi lainnya.

Hasil studi pendahuluan menunjukkan bahwa kurangnya pemahaman mahasiswa terhadap dasar- dasar akuntansi disebabkan oleh beberapa faktor salah satu faktor penyebabnya adalah cara mengajar dosen yang masih menggunakan metode lama yakni ceramah dan diskusi kelompok. Dosen dalam membelajarkan akuntansi dasar menggunakan metode ceramah dan membagi mahasiswa ke dalam kelompok- kelompok yang kemudian setiap kelompok diberikan materi yang akan dikaji. Setiap kelompok akan melakukan presentase dari materi yang sudah dibagikan di setiap pertemuan dan akan memimpin jalannya diskusi, sementara dosen akan memberikan komentar di akhir pertemuan. Sebagian besar mahasiswa merasa kesulitan memahami akuntansi dasar dengan metode diskusi kelompok yang mengharuskan mereka melakukan presentase, sementara pengetahuan mereka terhadap akuntansi dasar masih sangat minim, selain itu belajar otodidak dari membaca refrensi pun menjadikan mereka tambah kebingungan. Mahasiswa berharap dosen memberikan penjelasan yang rinci dan bertahap terkait proses penyelesaian kasus- kasus dalam akuntanasi baru kemudian memberikan kesempatan kepada mereka untuk mencoba menyelesaikan kasus- kasus serupa dan memberikan tugas- tugas terkait, sehingga mereka lebih faham dan mampu untuk menyelesaikan setiap kasus yang diberikan.

Salah satu solusi untuk menjawab keinginan dan kebutuhan mahasiswa tersebut adalah dengan penggunaan model pengajaran langsung. Model pengajaran atau pembelajaran langsung biasa disebut direct instruction (DI) dirancang khusus untuk menunjang proses pembelajaran yang berkaitan dengan pengetahuan prosedural dan pengetahuan deklaratif yang terstruktur dengan baik, yang dapat diajarkan dengan pola kegiatan yang bertahap, selangkah demi selangkah. Model ini dapat membantu mahasiswa untuk memepelajari pengetahuan dan keterampilan dasar yang dijelaskan secara prosedural selangkah demi selangkah. Penggunaan model direct instruction rencananya akan coba diterapkan pada pokok bahasan penyusunan laporan keuangan. Laporan keuangan terdiri dari laporan laba rugi, laporan perubahan ekuitas, neraca dan arus kas yang saling terkait dalam penyusunannya sehingga memerlukan lembar kerja berupa worksheet sebagai alat bantu untuk penyususanan laporan keuangan tersebut. Khusus untuk penyusunan laporan arus kas untuk menyususnnya masih diperlukan informasi tambahan mengenai perubahan pada saldo akun. Sehingga pada penelitian ini penggunaan model direct instruction akan dipadukan dengan media worksheet untuk meningkatkan pemahaman akuntansi dasar pada materi penyusunan laporan keuangan, dimana laporan keuangan yang dimaksud yaitu laporan laba rugi, laporan perubahan modal dan neraca.

\section{Metode}

Penelitian ini adalah penelitian tindakan (action reaserch), subjek dalam penelitian ini adalah Mahasiswa Pendidikan Akuntansi FKIP Universitas Gunung Rinjani semester 2, teknik pengumpulan data dengan Observasi partisipan, wawancara semi struktur, dokumen analisis dan tes. Sementara itu teknik analisis data dilakukan dengan metode kombinasi tipe convergent parallel mixed methods yaitu peneliti mengumpulkan data kuantitatif dan kualitatif pada waktu yang sama, kemudian melakukan analisis data secara terpisah lalu membandingkan hasilnya dengan tujuan untuk mengetahui apakah temuan tersebut saling melengkapi atau tidak(Sugiyono, 2015). Data kuantitatif 
dalam penelitian ini adalah hasil tes pemahaman, kemudian data kualitatif berupa hasil observasi, wawancara dan dokumentasi.

Berikut adalah prosedur penelitian tindakan yang akan dilakukan dibagi ke dalam beberapa kegiatan sebagai berikut:

a. Perencanaan tindakan

Perencanaan yang dilakukan meliputi: membuat rencana pelaksanaan pembelajaran dan menyiapkan instrumen untuk mengukur pemahaman akuntansi dasar materi penyusunan laporan keuangan.

b. Pelaksanaan tindakan

Rencana yang telah disusun kemudian dilaksanakan, yaitu pelaksanaan pembelajaran akuntansi dasar dengan model direct instruction dipadukan dengan media worksheet.

c. Observasi dan interpretasi

Selama tindakan dilaksanakan (proses pembelajaran), peneliti melakukan pengamatan dan menginterpretasikan bagaimana kondisi pembelajaran.

d. Analisis dan refleksi

Proses analisis dan refleksi dilakukan terhadap kegiatan pembelajaran yang telah dilakukan dan hasil yang telah dicapai. Melakukan analisis dan refleksi terhadap pelaksanaan pembelajaran, apakah sudah sesuai dengan apa yang telah direncanakkan sebelumnya, kemudian hasil yang dicapai apakah sudah sesuai dengan tujuan yang ditargetkan. Jika tujuan belum tercapai yakni meningkatkan pemahaman akuntansi mahasiswa maka akan dicari penyebabnya. Setelah kesalahan diperbaiki, maka dilanjutkan dengan siklus ke 2, untuk membuktikan apakah perbaikan yang dilakukan efektif atau tidak. Jika tujuan sudah tercapai maka dilanjutkan ke siklus ke 3 untuk mengetahui konsistensi tindakan yang telah dilakukan.

\section{Hasil dan pembahasan}

Berikut adalah hasil penelitian dimulai dari sebelum tindakan sampai setelah tindakan diberikan

Pratindakan

Tahap pratindakan merupakan tahap sebelum tindakan diberikan. Berikut akan dijabarkan data kuantitatif dan data kualitatif pada tahap pratindakan.

Tabel 1. Hasil Tes Pemahaman dasar akuntansi mahasiswa pada tahap Pratindakan

\begin{tabular}{lll}
\hline No & Nama Mahasiswa & Nilai \\
\hline 1 & Mahasiswa-1.1 & 20 \\
2 & Mahasiswa-1.2 & 20 \\
3 & Mahasiswa-1.3 & 20 \\
4 & Mahasiswa-1.4 & 20 \\
5 & Mahasiswa-1.5 & 20 \\
6 & Mahasiswa-1.6 & 20 \\
7 & Mahasiswa-1.7 & 20 \\
8 & Mahasiswa-1.8 & 20 \\
9 & Mahasiswa-1.9 & 20 \\
10 & Mahasiswa-1.10 & 20 \\
11 & Mahasiswa-1.11 & 20 \\
12 & Mahasiswa-1.12 & 20 \\
13 & Mahasiswa-1.13 & 20 \\
14 & Mahasiswa-1.14 & 20 \\
15 & Mahasiswa-1.15 & 20 \\
\hline Total & & 300 \\
\hline Rata- Rata & & 20 \\
\hline
\end{tabular}

Hasil Data Kualitatif pemahaman dasar akuntansi mahasiswa program studi pendidikan akuntansi Universitas Gunung Rinjani pada Tahap Pratindakan.

Simpulan dari wawancara dan observasi pada tahap pratindakan adalah sebagai berikut:

a. Proses pembelajaran dasar- dasar akuntansi atau pengantar akuntansi selama ini dilakukan dengan metode diskusi kelompok dimana dosen membagi mahasiswa kedalam beberapa kelompok kemudian memberikan masing- masing kelompok materi yang akan dibahas, selain itu dosen juga 
menjelaskan materi dengan bantuan slide presentasi dan memberikan umpan berupa beberapa pertanyaan kepada mahasiswa dan mempersilahkan mahasiswa untuk bertanya .

b. Praktik akuntansi belum pernah dilakukan

c. Mahasiswa masih pasif dalam pembelajaran

d. Pertanyaan yang diajukan mahasiswa sering kali di luar konteks materi pembelajaran

e. Mahasiswa merasa belum memahami dasar- dasar akuntansi

f. Mahasiswa belum mengenal persamaan dasar akuntansi karena yang dibelajarkan selama ini adalah teori akuntansi

g. Mahasiswa belum mengetahui siklus akuntansi

$\mathrm{h}$. Mahasiswa belum mengenal laporan keuangan dan apa saja yang ada didalam laporan keuangan

i. Mahasiswa belum mampu membuat laporan keuangan

j. Mahasiswa menginginkan pembelajaran akuntanasi dengan lebih banyak praktik dibandingkan dengan teori, mereka juga menginginkan untuk dijelaskan secara terperinci terkait proses pengerjaan dalam akuntansi.

Adapun ringkasan hasil wawancara dan observasi terkait pemahaman dasar akuntansi mahasiswa pada materi penyusunan laporan keuangan dengan memanfaatkan media worksheet adalah sbb.

Tabel 2. Ringkasan wawancara

\begin{tabular}{ll}
\hline \multicolumn{1}{c}{ Aspek } & \multicolumn{1}{c}{ Hasil } \\
\hline $\begin{array}{l}\text { Penggunaan } \\
\text { Worksheet } \\
\text { Penyusunan Laba/Rugi }\end{array}$ & $\begin{array}{l}\text { Mahasiswa belum pernah menggunakan worksheet } \\
\text { membuat laporan laba rugi }\end{array}$ \\
$\begin{array}{l}\text { Penyusunan } \\
\text { Perubahan Modal Laporan } \\
\text { Penyusunan Neraca }\end{array}$ & $\begin{array}{l}\text { Mahasiswa belum pernah membuat laporan perubahan modal sehingga belum bisa } \\
\text { membuatnya } \\
\text { Mahasiswa belum pernah Menyusun neraca serhinnga belum mampu membuat } \\
\text { neraca. }\end{array}$ \\
\hline
\end{tabular}

\section{Tindakan Siklus 1}

Tabel 3. Hasil Tes Pemahaman akuntansi dasar mahasiswa pada Sklus 1

\begin{tabular}{lll}
\hline No & Nama Mahasiswa & Nilai \\
\hline 1 & Mahasiswa-1.1 & 50 \\
2 & Mahasiswa-1.2 & 60 \\
3 & Mahasiswa-1.3 & 0 \\
4 & Mahasiswa-1.4 & 50 \\
5 & Mahasiswa-1.5 & 50 \\
6 & Mahasiswa-1.6 & 50 \\
7 & Mahasiswa-1.7 & 50 \\
8 & Mahasiswa-1.8 & 50 \\
9 & Mahasiswa-1.9 & 50 \\
10 & Mahasiswa-1.10 & 60 \\
11 & Mahasiswa-1.11 & 60 \\
12 & Mahasiswa-1.12 & 60 \\
13 & Mahasiswa-1.13 & 50 \\
14 & Mahasiswa-1.14 & 50 \\
15 & Mahasiswa-1.15 & 50 \\
\hline Total & & 740 \\
\hline Rata- Rata & & 49.333 \\
\hline
\end{tabular}

Hasil Data Kualitatif pemahaman dasar akuntansi mahasiswa program studi pendidikan akuntansi Universitas Gunung Rinjani pada Siklus 1 siklus 1:

Berikut adalah simpulan dari wawancara dan observasi yang dilakukan selama proses tindakan 
a. Proses pembelajaran dasar- dasar akuntansi atau pengantar akuntansi dilakukan dengan model direct instruction melalui 5 fase yaitu tahap penyampaian tujuan, demonstrasi/presentasi, latihan terbimbing, melakukan pengecekan terhadap pemahaman dasar mahasiswa dan memberikan ummpan balik, selain itu mahasiswa juga diberikan kesempatan untuk melakukan praktik dengan latihan lanjutan.

b. Mahasiwa mulai aktif selama proses pembelajaran

c. Terdapat 1 mahasiswa yang tidak hadir selama siklus 1

d. Praktik akuntansi tetap dilakukan oleh mahasiswa baik di kampus maupun di rumah

e. Pertanyaan yang diajukan mahasiswa sesuai dengan materi yang sedang dipelajari

f. Mahasiswa merasa mulai memahami akuntansi

g. Mahasiswa sudah mengenal persamaan dasar akuntansi dan mampu menganalisis transaksi dan pengaruhnya terhadap persamaan dasar serta membuat laporan keuangan dari persamaan dasar yang telah dibuat

h. Mahasiswa mulai mengetahui siklus akuntansi dan mulai memahami sedikit- demi sedikit meskipun belum mampu menyelesaikan 1 siklus akuntansi perusahaan jasa dengan sempurna

i. Mahasiswa sudah mengenal laporan keuangan dan apa saja isi dari laporan keuangan

j. Mahasiswa sudah mengenal neraca lajur sebagai media yang membantu dalam membuat laporan keuangan meskipun belum mampu menyelesaikan neraca lajur dengan sempurna

k. Mahasiswa belum mampu menyelesaikan laporan keuangan dengan sempurna

l. Mahasiswa merasa senang belajar akuntansi seperti ini, karena merasa dijelaskan secara rinci tahap per tahap dalam proses pengerjaannya, selain itu mereka juga merasa sengan bisa melakukan praktik akuntansi secara berkelanjutan.

Adapun ringkasan hasil wawancara dan observasi terkait pemahaman dasar akuntansi mahasiswa pada materi penyusunan laporan keuangan dengan memanfaatkan media worksheet adalah sbb.

Tabel 4. Ringkasan wawancara

\begin{tabular}{ll}
\hline \multicolumn{1}{c}{ Aspek } & \multicolumn{1}{c}{ Hasil } \\
\hline $\begin{array}{l}\text { Penggunaan media } \\
\text { Worksheet }\end{array}$ & $\begin{array}{l}\text { Mahasiswa sudah menggunakan media worksheet sebagai alat bantu dalam membuat } \\
\text { laporan keuangan } \\
\text { Penyusunan Laba/Rugi } \\
\text { Mahasiswa belum mampu Menyusun laba rugi dengan sempurna, sudah benar dari sisi } \\
\text { struktur isi namun masih keliru di nominal }\end{array}$ \\
$\begin{array}{l}\text { Penyusunan Laporan } \\
\text { Perubahan Modal } \\
\text { Penyusunan Neraca }\end{array}$ & $\begin{array}{l}\text { Mahasiswa belum mampu Menyusun laporan perubahan modal dengan sempurna, sudah } \\
\text { Mahasiswa belum mampu Menyusun neraca dengan sempurna, secara structural isi } \\
\text { sudah benar namu secara nominal masih keliru }\end{array}$ \\
\hline
\end{tabular}

\section{Tindakan Siklus 2}

Tabel 5. Hasil Tes Pemahaman akuntansi dasar mahasiswa siklus 2

\begin{tabular}{lll}
\hline No & Nama Mahasiswa & Nilai \\
\hline 1 & Mahasiswa-1.1 & 98 \\
2 & Mahasiswa-1.2 & 90 \\
3 & Mahasiswa-1.3 & 0 \\
4 & Mahasiswa-1.4 & 75 \\
5 & Mahasiswa-1.5 & 75 \\
6 & Mahasiswa-1.6 & 85 \\
7 & Mahasiswa-1.7 & 75 \\
8 & Mahasiswa-1.8 & 80 \\
9 & Mahasiswa-1.9 & 75 \\
10 & Mahasiswa-1.10 & 98 \\
11 & Mahasiswa-1.11 & 95 \\
12 & Mahasiswa-1.12 & 95 \\
13 & Mahasiswa-1.13 & 90 \\
14 & Mahasiswa-1.14 & 85 \\
115 & Mahasiswa-1.15 & 85 \\
\hline Total & & 1201 \\
\hline
\end{tabular}


Rata- Rata 80.0667

Hasil Data Kualitatif pemahaman dasar akuntansi mahasiswa program studi pendidikan akuntansi Universitas Gunung Rinjani pada Siklus 2. Berikut adalah simpulan dari observasi dan wawancara Siklus 2

a. Proses pembelajaran dasar- dasar akuntansi atau pengantar akuntansi dilakukan dengan model direct instruction melalui 5 fase yaitu tahap penyampaian tujuan, demonstrasi/presentasi, latihan terbimbing, melakukan pengecekan pemahaman kemudian memberikan umpan balik, serta memberikan kesempatan untuk melakukan latihan lanjutan dan penerapan.

b. Mahasiwa aktif selama proses pembelajaran, aktif menjawab pertanyaan, aktif bertanya, aktif menyelesaikan tugas dan latihan dengan menyelesaikan kasus di papan tulis di hadapan temantemannya

c. Terdapat 1 mahasiswa yang tidak hadir selama siklus 2

d. Praktik akuntansi tetap dilakukan oleh mahasiswa baik di kampus maupun di rumah

e. Mahasiswa merasa mulai memahami akuntansi dasar

f. Mahasiswa mampu mengisi worksheet dan menjadikannya sebagai media yang membantu dalam penyusunan laporan keuangan.

g. Mahasiswa mampu menyusun laporan keuangan perusahaan jasa

Adapun ringkasan hasil wawancara dan observasi terkait pemahaman dasar akuntansi mahasiswa pada materi penyusunan laporan keuangan dengan memanfaatkan media worksheet adalah sbb.

Tabel 6. Hasil wawancara

\begin{tabular}{ll}
\hline \multicolumn{1}{c}{ Aspek } & \multicolumn{1}{c}{ Hasil } \\
\hline Penggunaan media & $\begin{array}{l}\text { Mahasiswa menggunakan media worksheet sebagai alat bantu dalam membuat laporan } \\
\text { Worksheet }\end{array}$ \\
$\begin{array}{l}\text { Penyangan } \\
\text { Penyusunan Laba/Rugi }\end{array}$ & $\begin{array}{l}\text { Mahasiswa mampu Menyusun laba rugi dengan benar } \\
\text { Perubahan Modal }\end{array}$ \\
Penyusunan Neraca & Mahasiswa mampu Menyusun laporan perubahan modal dengan benar \\
\hline
\end{tabular}

\section{Tindakan Siklus 3}

Tabel 7. Hasil Tes Pemahaman akuntansi dasar mahaMahasiswa

\begin{tabular}{lll}
\hline No & Nama Mahasiswa & Nilai \\
\hline 1 & Mahasiswa-1.1 & 100 \\
2 & Mahasiswa-1.2 & 100 \\
3 & Mahasiswa-1.3 & 0 \\
4 & Mahasiswa-1.4 & 85 \\
5 & Mahasiswa-1.5 & 85 \\
6 & Mahasiswa-1.6 & 85 \\
7 & Mahasiswa-1.7 & 85 \\
8 & Mahasiswa-1.8 & 80 \\
9 & Mahasiswa-1.9 & 75 \\
10 & Mahasiswa-1.10 & 100 \\
11 & Mahasiswa-1.11 & 100 \\
12 & Mahasiswa-1.12 & 100 \\
13 & Mahasiswa-1.13 & 100 \\
14 & Mahasiswa-1.14 & 85 \\
15 & Mahasiswa-1.15 & 85 \\
\hline Total & & 1265 \\
\hline Rata- Rata & & 84.333 \\
\hline
\end{tabular}

Hasil Data Kualitatif pemahaman dasar akuntansi mahasiswa program studi pendidikan akuntansi Universitas Gunung Rinjani pada Siklus 3. Hasil observasi dan wawancara siklus 3 disimpulkan sebagai berikut:

a. Proses pembelajaran dasar- dasar akuntansi atau pengantar akuntansi dilakukan dengan model direct instruction melalui 5 fase yaitu tahap penyampaian tujuan, demonstrasi/presentasi, pelatihan 
terbimbing, melakukan pengecekan terhadap pemahaman serta memberikan umpan balik, dan memberikan kesempatan untuk latihan lanjutan dan penerapan.

b. Mahasiwa aktif selama proses pembelajaran, aktif menjawab pertanyaan, aktif bertanya, secara bergantian maju ke depan untuk menyelesaikan kasus

c. $\quad$ Terdapat 1 mahasiswa yang tidak hadir selama siklus 3

d. Praktik akuntansi tetap dilakukan oleh mahasiswa baik di kampus maupun di rumah

e. Mahasiswa merasa mulai memahami akuntansi dasar

f. Mahasiswa mampu mengisi worksheet dan menjadikannya sebagai media untuk membantu mahasiswa dalam proses penyusunan laporan keuangan

g. Mahasiswa mampu menyusun laporan keuangan perusahaan jasa

Adapun ringkasan hasil wawancara dan observasi terkait pemahaman dasar akuntansi mahasiswa pada materi penyusunan laporan keuangan dengan memanfaatkan media worksheet adalah sbb.

Tabel 8. Hasil wawancara

\begin{tabular}{|c|c|}
\hline Aspek & Hasil \\
\hline $\begin{array}{l}\text { Penggunaan media } \\
\text { Worksheet }\end{array}$ & $\begin{array}{l}\text { Mahasiswa menggunakan media worksheet sebagai alat bantu dalam membuat } \\
\text { laporan keuangan }\end{array}$ \\
\hline Penyusunan Laba/Rugi & Mahasiswa mampu Menyusun laba rugi dengan benar \\
\hline $\begin{array}{l}\text { Penyusunan Laporan } \\
\text { Perubahan Modal }\end{array}$ & Mahasiswa mampu Menyusun laporan perubahan modal dengan benar \\
\hline Penyusunan Neraca & Mahasiswa mampu mampu Menyusun neraca benar \\
\hline
\end{tabular}

Penelitian ini menemukan bahwa penggunaan model DI dengan media worksheet mampu meningkatkan pemahaman dasar akuntansi mahasiswa pada materi penyusunan laporan keuangan. Peningkatan pemahaman mahasiswa ditunjukkan dengan berbagai perubahan dalam kemampuan mahasiswa dari segi kemampuan mahasiswa dalam menyusun laporan laba rugi, kemampuan mahasiwa dalam menyusun laporan perubaha modal, dan kemampuan mahasiswa dalam menyusun neraca.

Berdasarkan hasil penelitian, kemampuan mahasiwa dalam menyusun laporan keuangan mengalami peningkatan. Sebelum menerima tindakan mahasiswa belum mengenal apa itu laporan keuangan, apa saja isi dari laporan keuangan serta bagaimana cara membuat laporan keuangan. Mahasiswa sebelum menerima tindakan juga belum mengenal apa itu worksheet. Selain itu mahasiswa juga belum pernah melakukan praktik penyelesaian kasus dalam akuntansi. Setelah menerima tindakan siklus 1 mahasiswa mulai mengenal laporan keuangan dalam akuntansi perusahaan saja. Selain mengenal mahasiswa juga mulai memahami apa saja yang termasuk ke dalam laporan keuangan dan bagaimana proses pembuatan laporan keuangan. Meskipun pada siklus 1 mahasiswa belum berhasil membuat laporan keuangan dengan benar dan akurat namun biladibandingkan dengan tahap pra tindakan, pemahaman mahasiswa terkait akuntansi dasar dalam hal ini penyusunan laporan keuangan sudah mulai meningkat. Mahasiswa juga sudah mengenal worksheet dan cara pengisiannya. Selain mulai mengenal, mahasiswa juga sudah mulai melakukan praktik penyusunan laporan keuangan menggunakan media worksheet. Meskipun demikian tindakan pada siklus 1 ini masih belum dapat dikatakan berhasil, ini dikarenakan beberapa indikator keberhasilan tindakan pada penelitian ini belum tercapai.

Pada siklus 2 pemahaman mahasiswa kembali meningkat, ditandai dengan keberhasilan mahasiswa dalam mebuat laporan keuangan. Selain mengenal, mahasiswa sudah berhasil membuat laporan keuangan dengan akurat selama proses pembelajaran berlangsung, meskipun demikian saat tes akhir pada siklus 2 ternyata terdapat beberapa kekeliruan di beberapa bagian penempatan nominal akun sehingga pada siklus 2 belum ada mahasiswa yang mendapatkan nilai sempurna. Meskipun demikian tindakan pada siklus 2 ini dinyatakan berhasil, dikarenakan semua indikator keberhasilan tindakan pada siklus 2 ini tercapai semua. Sama halnya dengan yang terjadi pada siklus 3. Tindakan pada siklus 3 juga berhasil hal ini terlihat dari ketercapaian indikator keberhasilan tindakan yang telah ditentukan sebelumnya. Pada siklus 3 terdapat 6 mahasiswa dari total 15 mahasiswa yang mampu mendapatkan nilai sempurna. Ini tentu merupakan peningkatan pemahaman dari siklus sebelumnya. Peningkatan pemahaman dasar akuntansi mahasiswa juga ditandai dengan peningkatan pada nilai rata-rata mahasiswa terkait dengan pemahaman dasar akuntansi yakni dari 20,00 pada tahap pratindakan menjadi 49.33 setelah pemberian tindakan siklus 1 dan kembali meningkat menjadi 80,67 setelah pemberian tindakan siklus 2, kemudian kembali meningkat menjadi 84.33 pada siklus 3. Pada siklus 2 dan 3 sejumlah 93,33\% mahasiswa berhasil meningkatkan pemahaman dasar akuntansi yang dimiliki. 
Penerapan model DI dengan media worksheet pada mata kuliah akuntansi mampu meningkatkan pemahaman dasar akuntansi mahasiswa di Universitas Gunung Rinjani Lombok. Hal ini tentu tidak terlepas dari berbagai kelebihan dari model DI yaitu; 1) model pembelajaran langsung ini dapat memberikan tantangan kepada siswa/mahasiswa dalam mempertimbangkan kesenjangan yang terdapat di antara teori dengan kenyataan 2) memungkinkan siswa/mahasiswa untuk berkonsentrasi pada hasil dari suatu tugas dan bukan teknik- teknik dalam menghasilkannya, 3) saat model ini dugnakan dengan efektif maka dapat menjadikan siswa/mahasiswa yang tidak dapat mengarahkan diri sendiri sekalipun mampu meraih prestasi, 4) model ini bergantung pada kemampuan refleksi pendidik sehingga pendidik dapat terus menerus melakukan evaluasi terhadap proses pembelajaran, 5) dapat digunakan untuk menekankan poinpoin penting atau kesulitan- kesulitan yang mungkin dihadapi siswa/mahasiswa sehingga hal- hal tersebut dapat diungkapkan (Sari, 2013). Kemampuan model DI dalam meningkatkan pemahaman juga dijelaskan oleh (Aisyaturrahmi, 2016) yang menjelaskan bahwa model DI sebagai suatu model pembelajaran dimana kegiatannya terfokus pada aktivitas- aktivitas akademik, sehingga di dalam implementasi kegiatan pembelajaan pendidik melakukan kontrol yang ketat terhadap kemajuan belajar siswa, pendayagunaan waktu serta iklim kelas dikontrol secara ketat. Sedangkan dampak pengajarannya adalah tercapainnya ketuntasan muatan akademik dan keterampilan, meningkatnya motivasi belajar siswa serta meningkatnya kemampuan siswa. Sementara dampak pengiringnya adalah meningkatnya kepercayaan diri siswa.

Model DI merupakan sebuah model pembelajaran yang dirancang untuk menunjang proses pembelajaran siswa/mahasiswa yang berkaitan dengan pengetahuan prosedural yang terstruktur dengan baik yang dapat diajarkan dengan pola kegiatan yang bertahap, selangkah demi selangkah (Pritandhari, 2017; Sari, 2013; Sawining, 2019). Adapun Langkah-langakah dalam penerapan model DI yaitu 1) memaparkan tujuan pembelajaran serta menyiapkan siswa untuk belajar, 2) melakukan demonstrasi keterampilan atau mempresentasikan pengetahuan, 3) memberikan pelatihan dan pembimbingan, 4) melakukan pengecekan terhadap pemahaman dan memberikan umpan balik, dan 5) memberikan kesempatan untuk pelatihan lanjutan dan penerapan (Cahyo, 2019; Masni, 2019; Nur, 2011; Sawining, 2019; Zahriani, 2014). Lebih lanjut (Masni, 2019; Sitompul, 2019) memaparkan sintaks model DI yang disajikan dalam lima fase atau tahapan sebagai berikut

a. Orientiation

Pada tahap orientasi, pendidik dalam hal ini dosen memaparkan latar belakang pelajaran, tujuan pembelajaran dan informasi terkait pelajaran serta pentingnya pelajaran ini. Selain itu dosen juga mempersiapkan mahasiswa untuk belajar

b. Demonstration

Pada tahap demonstrasi dilakukan dengan kegiatan dosen dalam mendemonstrasikan suatu keterampilan secara bertahap langkah demi langkah dengan benar.

c. Latihan Terbimbing

Dalam tahap ini, dosen merencanakan bimbingan pada mahasiswa dan melakukan pembimbingan untuk melakukan latihan awal

d. Cek Pemahaman dan Umpan Balik

Pada tahapan ini, dosen mengecek apakah mahasiswa telah berhasil melakukan tugas dengan baik, setelah itu dosen akan memberikan umpan balik

e. Siswa/mahasiswa melakukan latihan lanjutan dan melakukan penerapan

Di tahap ini dosen memberikan kesempatan melakukan pelatihan lanjutan, dengan menitik beratkan kepada penerapan situasi yang lebih kompleks di kehidupan sehari-hari.

Keberhasilan penerapan model DI pada penelitian ini tidak terlepas juga dari kecocokan karakteristiknya dengan karakteristik pembelajaran akuntansi yang membutuhkan penjelasan rinci secara prosedural secara bertahap selangkah demi selangkah. Tidak hanya pada penelitian ini, beberapa penelitian sebelumnya juga menunjukkan kecocokan penggunaan model ini saat diterapkan pada pembelajaran akuntansi baik pada tingkat sekolah menengah maupun universitas, seperti hasil penelitian yang dijabarkan oleh (Sari, 2013) yang meneliti tentang penerapan model DI untuk meningkatkan pemahaman bejalar siswa menemukan hasil bahwa penerapan DI dapat meningkatkan pemahaman belajar siswa pada kompetensi dasar membuat jurnal penyesuaian melalui media kertas kerja. Sejalan dengan itu (Usman, 2013)juga menemukan bahwa model DI dapat meningkatkan kemampuan siswa menyusun laporan keuangan, kemampuan kognitif dan psikomotor siswa meningkat setelah penerapan model DI.

Selain itu (Sidik NH, 2016)yang meneliti tentang peningkatan hasil belajar siswa melalui penerapan model pembelajaran DI memaparkan hasil penelitiannya yang menunjukkan bahwa keberhasilan model ini dalam meningkatkan hasil belajar siswa. Sejalan dengan itu (Ridho, 2015)dalam penelitiannya menemukan bahwa penggunaan model $D I$ lebih efektif bila dibandingkan dengan model probleme based learning pada mata pelajaran komputer akuntansi. Sementara itu, (Aisyaturrahmi, 2016)yang meneliti di tingkat universitas juga menemukan bahwa pembelajaran dengan case base learning yang dipadukan dengan DI 
berjalan lancar sesuai perencanaan, mahasiswa memberikan respon yang positif. Selain itu mahasiswa juga merasa tertarik dan senang dalam mengikuti proses pembelajaran sehingga memudahkan mereka dalam memahami materi yang disampaikan oleh dosen. Penggunaan metode ini juga berhasil meningkatkan hasil belajar mahasiswa pada mata kuliah akuntansi keuangan lanjutan. Hasil penelitian (Sitompul, 2019) juga menunjukkan bahwa penggunaan model DI berbasis Games mampu mempengaruhi minat belajar mahasiswa. Minat belajar mahasiswa yang diberikan perlakuan dengan model DI lebih baik dibandingkan dengan tanpa penggunaan model DI. Lebih lanjut (Sitompul, 2019)menyarankan agar para pendidik dalam hal ini dosen dapat menggunakan model DI dalam membelajarkan akuntansi karena pembelajaran dengan model DI lebih membantu mahasiswa dalam memahami konsep- konsep prosedural sesuai dengan karakteristik akuntansi.

\section{Simpulan dan saran}

Penemuan dari penelitian ini menunjukkan bahwa penggunaan model DI dengan media worksheet berhasil meningkatkan pemahaman dasar akuntansi mahasiswa pada materi penyusunan laporan keuangan. Peningkatan pemahaman mahasiswa ditunjukkan dengan berbagai perubahan dalam kemampuan mahasiswa dari segi kemampuan mahasiswa dalam menyusun laporan laba rugi, kemampuan mahasiwa dalam menyusun laporan perubaha modal, dan kemampuan mahasiswa dalam menyusun neraca. Peningkatan pemahaman dasar akuntansi mahasiswa juga ditandai dengan peningkatan pada nilai rata-rata pemahaman dasar akuntansi yakni nilai rata-rata mahasiswa dari 20,00 pada tahap pratindakan menjadi 49.33 setelah tindakan siklus 1 dan kembali meningkat menjadi 80,67 setelah tindakan siklus 2 dan kembali meningkat menjadi 84.33 pada siklus 3. Pada siklus 2 dan 3 sejumlah 93,33\% mahasiswa berhasil meningkatkan pemahaman dasar akuntansi yang dimiliki.

Saran untuk penelitian selanjutnya, temuan dalam penelitian ini dapat dijadikan sebagai refrensi untuk penelitian selanjutnya. Selain itu, temuan ini juga dapat dijadikan pedoman untuk melakukan penelitian serupa dalam konteks yang sedikit berbeda sehingga dapat memperluas hasil dari penelitian terkait model DI. Peneliti yang tertarik untuk mengujicoba penggunaan model DI khususnya pada mata pelajaran akuntansi diharapkan meninjau pengaruhnya dari berbagai aspek tidak hanya dari aspek pemahaman saja tetapi juga bisa berkembang ke aspek lain seperti motivasi dan minat sehingga dapat menambah wawasan dalam dunia pendidikan.

\section{Daftar Rujukan}

Aisyaturrahmi. (2016). Case Base Learning dan Direct Instruction untuk Meningkatkan Keaktifan serta Hasil Belajar Studi pada Mahasiswa Mata Kuliah Akuntansi Keuangan Lanjutan. An-Nisbah, 2(2), 127-144.

Cahyo, E. D. (2019). Penggunaan Model Pembelajaran Direct Instruction untuk Meningkatkan Hasil Belajar Siswa pada Pelajaran Ilmu Pengetahuan Sosial. Jurnal Penelitian Ilmiah, 3(1), 39-59.

Masni. (2019). Upaya Peningkatan Kualitas Pembelajaran Akuntansi di Kelas X AK 2 SMKN 1 Solok Selatan melalui Penerapan Metode Direct Instruction Tahun Pelajaran 2017/2018. Jurnal Manajemen Dan Teknologi Pendidikan, 5(1), 74-84.

Nur, M. (2011). Pengajaran Langsung. UNESA University Press.

Pritandhari, M. (2017). Implementasi Pembelajaran Model Direct Instruction untuk Meningkatkan Kemampuan Berfikir Kreatif Mahasiswa. Jurnal Pendidikan Ekonomi UM Metro, 5 (1), 47-56, 5(1), 47-56.

Ridho, M. R. Ali. , Susilaningsih. , S. S. (2015). Studi Komparasi Kemampuan Siswa dengan Menggunakan Model Direct Instruction dan Model Problem Based Learning pada Mata Pelajaran Komputer Akuntansi di SMKN 1 Sukoharjo Kelas XI Akuntansi T.A. 2014/2015. Jurnal Tata Arta UNS, 1(1), 59-72.

Sari, D. Efita. , Susilaningsih. , I. E. (2013). Penggunaan Model Direct Instruction sebagai Upaya Peningkatan Pemahaman Siswa melalui Kertas Kerja. Jupe UNS, 2(1), 11-25.

Sawining, N. M. (2019). Implementasi Model Direct Instruction dengan Media Bentuk Geometri untuk Meningkatkan Prestasi Belajar Matematika Siswa Kelas V SD Negeri 2 Kalibukbuk. DAIWI WIDYA Jurnal Pendidikan, 6(1), 127-138.

Sidik NH, M. I. \& W. H. (2016). Meningkatkan Hasil Belajar Siswa melalui Penerapan Model Pembelajaran Direct Instruction. Jurnal Pendidikan Manajemen Perkantoran, 1(1), 49-60.

Sitompul, D. N. \& H. I. (2019). Pengaruh Model Pembelajaran Direct Instruction berbasis Games terha dap Minat Belajar Mahasiswa pada Mata Kuliah Pasiva Program Studi Pendidikan Akuntansi FKIP UMSU. Liabilitas Jurnal Pendidikan Akuntansi, 2(3), 243-253.

Sugiyono. (2015). Metode Penelitian Tindakan Komprehensif. Alfabeta. 
Usman. (2013). Penerapan Model Direct Instruction untuk Meningkatkan Kemampuan Siswa Menyusun Laporan Keuangan di SMK Negeri 1 Tarakan. Jurnal Pendidikan Humaniora, 1(3), 320-326.

Zahriani. (2014). Kontektualisasi Direct Instruction dalam Pembelajaran Sains. Lantanida Journal, 1(1), 95106. 